\title{
Quoted Discourse in Dutch News Narratives
}

\author{
Kirsten Vis, José Sanders and Wilbert Spooren
}

\section{Introduction}

News stories narrate newsworthy facts, events, and opinions. Most of the content of these stories comes from sources other than the news narrator. Reporters obtain their news from news sources, representing their utterances in more or less verbatim ways, paraphrasing and summarizing as they think necessary. The representation of source material can be described in terms of discourse presentation.

In this study, we adapt an existing model of discourse presentation to examine in detail, what journalistic narrators (henceforth: reporters) actually do when they represent words uttered previously by news sources, and how linguistic choices express the function such presentations may fulfil. In order to account for empirical phenomena in news corpora, we studied both recent and older news narratives, striving for a broad spectrum of discourse presentation phenomena. In a close reading of both present-day and historical news texts, these categories are investigated systematically in their functional contexts, and elaborated with several subcategories necessary to account for the empirical data.

The first section briefly addresses how quoted discourse is discussed and categorized in literature. In the second section, the material and method of analysis are outlined. The third section systematically investigates what types of quotation occur in a corpus of older and recent Dutch news texts. In the fourth section, the results are summarized and discussed for their implications.

\section{Categories of Quoted Language}

In a reported speech/writing/thought situation, there are at least two personae involved: the narrator and the person whose words or thoughts are represented. ${ }^{1}$

1 In journalistic narratives, this quoted person can also be the journalist as news source (Rennen, 2000).

(C) KIRSTEN VIS ET AL., 2015 | DOI 10.1163/9789004270848_010

This is an open access chapter distributed under the terms of the Creative Commons AttributionNoncommercial 3.o Unported (CC-BY-NC R.O) License, 


\begin{tabular}{lllll}
\hline & Indirect & Free indirect & Direct & Free direct \\
\hline Speech presentation: & IS & FIS & DS & FDS \\
Thought presentation: & IT & FIT & DT & FDT \\
Writing presentation: & IW & FIW & DW & FDW \\
\hline
\end{tabular}

The degree to which the voice of the narrator and the quoted person is heard in a text, can vary. Many descriptions are given of reported speech (and thought). As a starting point we use Semino and Short's (2004) model of discourse presentation, which consists of three scales: for speech, thought, and writing presentation. These scales involve several options, or categories, for presenting other people's utterances or thoughts, as represented in Table 8.1.

In the columns from left to right the categories of discourse presentation are named: Indirect Speech/Writing/Thought (Is/IW/IT); Free Indirect Speech/ Writing/Thought (FIS/FIW/FIT); Direct Speech/Writing/Thought (DS/DW/DT); and Free Direct Speech/Writing/Thought (FDS/FDW/FDT). Definitions and examples of all categories can be found in Semino and Short (2004: 10-16 and $42-52)^{2}$

Within the different types of speech or writing presentation, there are differences in the degree of (assumed) faithfulness to an original utterance, and hence the responsibility of the other person (Semino and Short, 2004). Canonically, a faithfulness claim is associated with direct speech or writing; it is assumed by readers that the directly quoted string reports exactly the words and structures used by the speaker in the original discourse, as in She said "Yes, I am right here." The direct mode is supposed to demonstrate what was said, thus expressing maximal faithfulness in discourse presentation (Clark and Gerrig, 1990). As such, it reaffirms both the presence of the witnessing narrator in the quoted situation and the trustworthiness of the quotation. By contrast, the indirect presentation mode displays a straight connection with what was said (the propositional content), but it does not convey how it was said (the words

2 Semino and Short (2004) also describe Narrator's Representation of Voice/Writing and Internal Narration (NV/NW/NI); Narrator's Representation of Speech/Writing/Thought Act (NRSA/NRWA/NRTA); these categories were not included in our analysis, since we aimed to describe those forms of discourse presentation in which the original news source has at least some involvement in the representation (either the content, or the wording, or both). 
and structures used to utter the relevant propositional content), as in She said that / confirmed she was present / was there. With respect to free indirect speech and writing, Semino and Short (2004) state that these categories involve a "mix" of the features associated with indirect speech/writing on the one hand and direct speech/writing on the other, as in Yes, she was right there. As a consequence, free indirect speech and writing are ambiguous with respect to the faithfulness claim concerning the wording of the utterance. Often it is difficult to decide whether it is the narrator/reporter or a character/news source who is responsible for a particular word; their voices are intertwined (cf. Sanders, 2010). Additionally, we distinguish partial quotations, by Semino and Short (2004: 159) described as subcategory of direct presentation in terms of "embedded quotation phenomena" (not in Table 8.1): relatively short stretches of text surrounded by inverted commas that occur within a non-direct form of speech/ writing/thought presentation, and that equal the direct and free direct categories with respect to faithfulness, as they seem to be a verbatim reproduction of a part of the original utterance.

\section{Material and Method}

In this paragraph, the material and the method of analysis in this study will be described. As material, a corpus of Dutch newspaper texts was assembled in two sub-corpora. The first sub-corpus consists of old newspaper texts from 1950 (32.579 words; $5^{0}$ texts), the second of recent newspaper texts from 2002 (51.587 words; 99 texts). Both sub-corpora were taken from five national Dutch newspapers (Algemeen Dagblad, NRC Handelsblad, Telegraaf, Trouw and Volkskrant) and eight sections (front page, domestic news, foreign news, financial news, culture, opinion, sports, science). The texts from 1950 were copied from microfilm, the 2002 texts were extracted from the international newspaper database Lexis Nexis.

All news texts in the corpus were closely read, marking out each instance of discourse presentation. The marked cases of discourse presentation were then analysed and categorized according to the degree in which a news source was involved in the representation of the content and/or wording, using the categories as presented in Table 8.1. Finally, consideration was given as to whether or not additional categories were needed to describe the empirical data.

In the next section, the results of our analysis are presented. For each category, typical cases are discussed and described both for linguistic characteristics and functional context. Attention is paid to any observed differences between the $195^{\circ}$ and 2002 cases. Finally, cases that did not fit into one of the 
pre-described categories are described and categorized linguistically, and characterized functionally.

\section{Results}

This section presents the findings for the speech presentation, writing presentation, and thought presentation categories, consecutively.

\section{Speech Presentation}

Direct Speech

In the newspaper corpus quotations are most frequently presented as direct speech, as in example (1). In this example a reporter presents an utterance of the deputy harbour master of the harbour of Zierikzee about a case of drug smuggling alleged to have occurred in the harbour. His words are marked by single inverted commas and a verb of communication, "zegt" ("says"), and the quoted material consists of three complete sentences. The quoted source is identified explicitly, both by name and by function. The explicit identification of the source marks him as being an authority. In combination with the other markers this is to assure the reader of the accuracy and precision of the quotation, thereby giving an assurance of the reporter's reliability (Weizman, 1984).

(1) "Op zich was er niets opvallends aan die mannen," zegt hulphavenmeester Ph. de Leeuw. "De afgelopen drie weken waren elke dag een paar mannen bezig op dat schip, maar niemand heeft iets geks gezien. $35^{\circ}$ Kilo drugs kun je in 10 Albert-Heijntassen zo naar binnen dragen." (Algemeen Dagblad, May 3 2002, domestic news)

"In itself there was nothing conspicuous about those men," says deputy harbour master Ph. de Leeuw. "For the last three weeks, every day, some men have been working on that ship, but no one has seen anything odd. You could carry 350 kilos of drugs inside in 10 large shopping bags without anyone noticing." ${ }^{3}$

The way of marking direct speech in example (1) is very common. Alternative ways of presenting direct speech often encountered in the corpus include alternative placement of the communicative verb (before the quotation rather than following it, as in example (2), the use of a colon (also in example (2)),

3 With respect to the translation of Dutch examples, this chapter provides glosses that retain the structure of the original as much as possible. 
and the use of a prepositional phrase with "aldus" or "volgens" ("according to") instead of a verb, see example (3).

(2) Na een slechte aanloop naar het Newyorkse evenement (drie overwinningen in drie toernooien) waarschuwde hij vriend en vijand: "Op de Us Open moet niemand mij afschrijven." (Trouw, September 7 2002, sports) After a bad run-up to the event in New York (only three matches won in his last in three tournaments) he warned friend and enemy alike: "At the us Open no one should write me off."

(3) “[... Ter handhaving van het recht en de wetten der menselijkheid kan hier alleen de zwaarste straf de juiste geacht worden", aldus mr. Van Voorst tot Voorst. (NRC Handelsblad, July 6 1950, domestic news)

"[... [ For the enforcement of the law and the laws of humanity only the severest penalty can be considered right", according to Mr Van Voorst tot Voorst, Master of Laws.

In addition to the options mentioned so far, some direct quotations in the 2002 subcorpus are introduced only by the name of the quoted source and a colon, leaving out the embedding phrase (communicative verb or phrase with "aldus" or "volgens"). Most often, such cases are not the first citation of this speaker in the article, and the source has been introduced previously, but infrequently it was not, or just vaguely introduced, as in example (4).

(4) Justitie spreekt over een "uitzonderlijk" vonnis. Persofficier I. van Hilten: "Nooit eerder is zo'n hoge straf opgelegd. Bij de meeste verkeersongelukken met dodelijke afloop wordt 'dood door schuld' ten laste gelegd. Hier bleek het haalbaar om drievoudige doodslag en een poging daartoe ten laste te leggen." (NRC Handelsblad, July 2 2002, domestic news)

The judiciary speaks of an "extraordinary" sentence. Press officer I. van Hilten: "Never before has such a high punishment been imposed. In most fatal traffic accidents cases the suspect is charged with 'culpable homicide.' In this case an indictment of triple culpable homicide and an attempted culpable homicide proved feasible."

Example (4) originates from an article on a lawsuit in the case of a fatal hitand-run accident. The first mention of press officer Van Hilten's name is in the second sentence, in the introduction of the stretch of direct speech. The only reference prior to this introduction that could possibly refer to the press officer is the word "justitie" in the previous sentence, referring to the judiciary in 
general: "all the judges in a country who, as a group, form part of the system of government" (Longman dictionary). Note that within the stretch of direct speech itself, a small fragment of three words ("dood door schuld") is marked with additional inverted commas. This phenomenon of inverted commas within inverted commas occurs more often and is discussed in the section on partial quotes, cf. example (21).

\section{Free Direct Speech}

The analysis shows some cases of free direct speech; a stretch of quotation, marked by inverted commas, but not introduced as such by a name, colon, communicative verb, or embedding phrase, as in example (5).

(5) Soekarno deelde mee, dat de actie tegen de Zuid-Molukken thans in volle gang is. "Wij zien ons gedwongen tegen de opstandelingen de wet van de vernietiging toe te passen." (Trouw, August 18 1950, foreign news)

Sukarno announced that the action against the South Moluccas is now well under way. "We are forced to enforce the law of destruction against the rebels."

The free direct quotation in the second sentence in example (5) is attributed to Sukarno, because in the preceding sentence an indirect quotation introduced by the communicative verb "deelde mee" ("announced") is attributed to him, and there is no other source available it could be attributed to. According to Semino and Short (2004), in press discourse, as opposed to e.g. fiction, free direct speech always follows another form of speech presentation which is clearly attributed to a source. However, our corpus contains examples where this is not the case, such as example (6). In the two sentences prior to the quotation, goalkeeper Grim of the soccer club Ajax, is introduced. Without an introduction, in the third sentence begins with a direct quotation. The fact that it starts immediately after the introduction of a person, and the fact that in the second sentence the speaker identifies himself as a goalkeeper, makes it clear that the stretch of quotation presents words uttered by Grim, even though there is no reporting clause for Grim for this stretch of quotation, nor any previous mention of a speech act involving Grim. However, the emotional expression "beladen" ("charged") in the first sentence facilitates the attribution of the direct quote to Grim by the implicit reference to his consciousness. ${ }^{4}$

4 A case of implicit viewpoint in terms of Sanders and Redeker (1993). 
(6) Voor Grim is de bekerfinale extra beladen. In de Kuip keept hij zijn laatste wedstrijd in het betaalde voetbal. "Dat realiseer ik me steeds meer. Ik weet al maanden dat mijn tijd als keeper er opzit, maar dat heb ik in de competitie steeds ver weg kunnen stoppen. Afgelopen week lukte dat echter niet meer. [...]." (Algemeen Dagblad, May 11 2002, sports)

For Grim the final is especially emotionally charged. The match in the Kuip [stadium] is his last match as a professional goalkeeper. "I realise that more and more. I have known for months that my time as a goalkeeper is finished, but during the competition I have been able to put that out of my mind. Last week that didn't work anymore. [...]."

The different ways of presenting direct speech discussed above, have one aspect in common: the quotations are always marked by single or double inverted commas. Only two articles were found in the entire corpus in which some fragments of direct speech are presented without inverted commas. In those two cases, direct quotations were recognizable from the use of the present tense within a past tense context, and a first person "I" referring to the quoted source rather than the reporter, as in example (7).

(7) Wat de interne politiek betreft zeide Soekarno te erkennen, dat er nog rampok is en dat er gewapende benden rondzwerven. Doch ik ben er zeker van, dat dit slechts tijdelijke verschijnselen zijn. (Trouw, August 18 1950, foreign news)

About the internal politics Sukarno said to acknowledge that there still are robberies and that armed gangs are roaming around. However I am sure that these are only temporary phenomena.

Note that all other verbs used in this text to report on the situation are in past tense, like "zeide" ("said"). ${ }^{5}$

\section{Indirect Speech}

In the corpus many cases were found where words of sources were presented as indirect speech. In example (8) both bold stretches are cases of indirect speech.

5 Typical for the direct presentation mode is that the deictic centre for time and place (here, now), for reference to persons and to verb tense is placed in the quoted source (Sanders and Redeker, 1996): I = source, now = present for the source. 
(8) Minister van Buitenlandse Zaken, Abdullah, zei dat uit inlichtingenrapporten blijkt dat Osama bin Laden en mullah Omar nog steeds in leven zijn, maar dat dat nog geen excuus is voor het ombrengen van burgers. Hij zei dat de jacht op Al-Qaeda en de Talibaan moet doorgaan, maar dat de procedures voor het lanceren van aanvallen moeten worden "herzien" om onschuldige slachtoffers te vermijden. (NRC Handelsblad, July 3 2002, foreign news)

Minister of Foreign Affairs, Abdullah, said that intelligence reports show that Osama bin Laden and mullah Omar are still alive, but that that is no excuse to kill civilians. He said that the hunt for AlQaeda and the Taliban should continue, but that the procedures for the launch of an attack should be "revised" to avoid innocent victims.

The indirect quotations in this example are marked by the verbs of communication ("zei" ("said") in both cases), the subordinating conjunction and the fact that they are dependent clauses. In fact, both indirect quotations in this example consist of two dependent clauses, coordinated by coordinating conjunction "maar" ("but"). The original speaker of the words, in this case Minister of Foreign Affairs, Abdullah, is responsible for the content of the quotation, but not (necessarily) for the wording, which may be paraphrased and summarized by the reporter depending on the article's style and length. Thus, the reporter can be held responsible for at least the words that are used to present the source material. Interestingly, in the last dependent clause in the example, one word ("herzien", "revised") is marked by inverted commas as quoted directly. This phenomenon is discussed extensively in the sub-section on partial quotes. Note that this stroke of indirect speech represents a news source who does not use Dutch. It is clear that non-Dutch speaking news sources are frequently represented indirectly, thus paraphrased by the journalist who would have had to translate their utterances anyway. Interestingly, both in the $195^{\circ}$ and 2002 examples, non-Dutch speaking news sources are also represented directly, as can be seen in examples (2), (5), and (7) above (sources: tennis player Pete Sampras and president Sukarno).

\section{Semi-direct Speech}

In the news texts in our subcorpus, a type of speech presentation is encountered fairly regularly that is not recognized as an individual type by Semino and Short (2004): semi-direct speech. This seems to be a mixed type in that it can neither be classified as direct nor as indirect speech. This complexity is evident in the other names given to this category: the term "semi-direct speech" introduced by Haeseryn et al. (1997) in their book on Dutch grammar, and 
"paratactic indirect speech" employed by Waugh (1995: 150). The stretches of semi-direct speech are similar to direct speech in form: the word order is that of an independent clause as it would be in direct speech, for in a dependent clause the finite verb is placed at the end, and the quotation is not introduced by a subordinating conjunction. In example (9), the bold stretch is attributed to the counsel for the defence by means of the embedding phrase "aldus" (according to").

(9) Deze dagvaarding is betrekkelijk de acte van beschuldiging tegen verdachte, aldus de verdediger; zij is ook de dagvaarding tegen iedere N.S.B.-er. (Telegraaf, March 10 1950, domestic news)

This summons relates to the indictment against the defendant, according to the counsel for the defence; it is also the summons against every N.S.B.member.

Semi-direct speech differs from direct speech, and resembles indirect speech, in the absence of inverted commas, and certain transformations in the finite verb and deictic elements referring to time, place and person; this is why example (7), with "I" referring to the quoted source, is categorized as direct speech and not as semi-direct speech. With regards to involvement of the original speaker, semi-direct speech is similar to indirect speech: the semi-direct speech mode involves a non-literal presentation of the words of another speaker (Haeseryn et al., 1997). This means that the original speaker is responsible for the content, but only marginally responsible for the wording. This is notable in the case of semi-direct speech in (10).

(10) De verslaafden houden zich overdag vooral op in de omgeving van de Mathenesserdijk. De buurt heeft al jaren te kampen met criminaliteit en overlast, zeggen de bewoners. (...) (NRC Handelsblad, July 4 2002, domestic news)

During the day, the addicted mostly linger around Mathenesserdijk. The neighbourhood has had to deal with criminality and nuisance for years, say the residents. [...]

The bold stretch in this example is not likely to be a literal quotation, as it is not very probable that the residents have all uttered this same sentence literally. In cases like these, the summarizing function of indirect (or semi-direct) speech is particularly evident (Semino and Short, 2004: 79). 


\section{Free Indirect Speech}

In the $195^{\circ}$ subcorpus, a type of discourse presentation occurs that cannot easily be categorized. Stretches of text were found that fail to satisfy formal criteria of direct or indirect forms of speech/writing/thought presentation in Table 8.1. However, there are strong indications, formal and functional, that the stretches do not represent words of the reporter, either. Cases like example (11) were found in seven articles, originating from various newspaper sections. This example was taken from a domestic news article on a court case against an alleged war criminal from World War II.

(11) Mr. Bottenheim voerde aan, dat verdachte geen kopstuk van de N.S.B. was geweest en desalniettemin al bijna vijf jaar detentie heeft ondergaan. Anderen, die belangrijker geacht kunnen worden, hebben echter het gevang al verlaten. $K$. heeft de Arbeiderspers uit de financiële débâcle gered en dat hij weinig kieskeurige middelen heeft toegepast, geeft hij toe. Het staat echter vast, dat hij oprecht berouw heeft. (Telegraaf, March 9 1950, domestic news)

Mr Bottenheim, Master of Laws, brought forward that the defendant had not been a head man of the N.S.B. and had nevertheless undergone five years of detention. Others, who can be considered more important, have however left the prison already. K. has saved the "Arbeiderspers" from a financial disaster and he admits that he has used not very discerning means. However, it is certain that he is sincerely remorseful.

The first sentence presents a stretch of indirect speech. For the subsequent sentences, however, the status is not as clear. The switch to present tense and the content of sentences 2 to 4 seem to indicate that they are direct speech: the main text of the article is in past tense, as is the first sentence of the example, yet in the sentence following the indirect speech there is a switch to present tense ("kunnen," "hebben"). This present tense is maintained up until the end of the fragment ("heeft gered," "geeft toe," "staat vast," "heeft"). With respect to the meaning of the sentences, it is likely that the bold sentences are quoted from Mr Bottenheim, the defendant's counsel, since it is hard to believe that the reporter himself would state that it is certain that the defendant's remorse is sincere. However, the bold sentences are not marked as direct speech by inverted commas. The finite verb "voerde aan" ("brought forward") in the first sentence functions as a signal that an indirect speech presentation will follow. Remarkably, the subsequent sentences should be understood as a continuation of the paraphrase of the words of Mr Bottenheim in the stretch of indirect speech, since reference is made to people and objects in a manner that is 
typical to thinking/speaking subject which functions as source - in this case Mr Bottenheim. ${ }^{6}$ Therefore the continued paraphrase is categorized as free indirect speech. Instances of free indirect speech in our corpus are limited to a specific type or articles, reporting on professional and formal meetings: court cases such as in example (11), a shareholders' meeting, an interview with a professor, a Upper Chamber assembly in Parliament, and a meeting with a mayor. It would seem that the high status of the quoted sources lead reporters to integrate the quoted material with their own prose in a practically unmarked manner.

Summarizing the results for speech representation, in our corpus we found cases of free direct, direct, and indirect speech presentation, while free indirect speech was found only infrequently in the 1950 subcorpus; in addition, semi-direct speech was found both in the 1950 and in 2002 subcorpora.

\section{Writing Presentation}

In addition to quoting from speaking sources, in the corpus reporters also quote from written sources, often scientific articles or expert reports. Similar to speech presentation, the quotations from writing are presented in direct, indirect and semi-direct mode.

\section{Direct Writing}

In the newspapers, reporters may quote directly from various written sources. Three examples of direct writing presentation are presented here, varying in the type of source that is quoted from:

(12) "Niet aanraken!," staat er in veelvoud geschreven op de wanden in Museum Boijmans Van Beuningen. (NRC Handelsblad, July 5 2002, cultural news)

"Do not touch!," is written multiple times on the walls of Museum Boijmans Van Beuningen.

(13) Als een Nederlandse krant schrijft over de dreiging van Rusland en over "vrees" spreekt in verband met de bewapening, dan schrijft ds. Strijd: "Hieraan kunnen en mogen Christenen niet meedoen. [...]" (Trouw, August 12 1950, opinion news)

6 For an extensive analysis of this case and similar cases in terms of embedded speech, see Lok (2009). 
When a Dutch newspaper writes on the threat of Russia and speaks of "fear" with regards to armament, minister Strijd writes: "Christians cannot and should not participate in this. [...]"

(14) "Ze geeft aan dat zij niets te maken heeft gehad met de dood van Rowena [...]," staat in een rapport van de Raad voor Kinderbescherming waarin De Telegraaf gisteren inzage had. (Telegraaf, March 6 2002, domestic news)

"She declares that she has not had anything to do with the death of Rowena [...]," [it] is written in a report for the Child Welfare Council that the journalist from De Telegraaf was given the opportunity to examine yesterday.

These examples share many formal and functional characteristics with the examples of direct speech: the stretches in quotation are marked by inverted commas, colons, and verbs that indicate writing, "staat geschreven" ("is written"), "schrijft" ("writes") and "staat" ("is written"). The sources of the quotations are usually explicitly described, either as the person who has written the words (13), or the location where the words are written (a report, as in (14)), or the walls in a museum, as in (12). Example (14) demonstrates that different (written and spoken) quotations can be embedded: the report, quoted directly by the reporter, indirectly presents statements made by Mrs Rikkers, Rowena's mother.

Similar to direct speech presentation, there are formal variations in the way direct quotations from a written source are presented, e.g. in word order through the different placements of the embedding verb (before, in the middle of, or after the quotation, in (13), (12) and (14) respectively), but these variations are more limited. For example, there are no occurrences of quotations from a written source in which only the name of the source and a colon are used (cf. example (4) for speech presentation). At least, there are no occurrences in which this source had been introduced explicitly as a written source in the preceding text. Usually, in cases where only a source name and colon introduce a quotation, the source is introduced more elaborately in one of the preceding lines. However, when such a context is not present, the quotation will by default be considered direct speech. Similarly, no examples of free direct quotation from a written source nor examples of writing presentation similar to the examples for embedded speech presentation (cf. example (11)) were found in the corpus. 


\section{Indirect Writing}

In the corpus, numerous cases of indirect writing presentation were encountered. Formally, these cases are quite similar to indirect speech presentation: only the embedding verbs are different, with the exception of verbs that can refer to communication both through speaking and through other modes of communication, such as writing. In example (15) two stretches of indirect presentation mode can be found. The second stretch is explicitly marked as writing presentation through the embedding verb "schrijft" ("writes"), while the first stretch is embedded through the verb "waarschuwt" ("warns"). This refers to communication with a particular purpose, but through no particular mode. The broader context of the example clarifies the source as an article by researcher Gershoff, published in a scientific journal.

(15) $[\ldots]$ Het is heel goed mogelijk dat agressieve kinderen vaker lichamelijk worden bestraft, juist omdat ze (om andere redenen) zo agressief zijn. Ook waarschuwt de onderzoeker, Elisabeth Thompson Gershoff van de Columbia Universiteit in New York, dat het hier specifiek om lichamelijke straf gaat en dat deze negatieve verbanden niet hoeven te gelden voor andere vormen van straf, zoals isolement ("op de gang!") of het intrekken van privileges. Sterker nog, ze schrijft dat opvoeding zonder enige bestraffing waarschijnlijk antisociaal gedrag van de kinderen sterk bevordert. (NRC Handelsblad, July 6 2002, science)

[... It is very well possible that aggressive children are more often physically punished, exactly because they are so aggressive (for other reasons). The researcher, Elisabeth Thompson Gershoff of Columbia University in New York, also warns that this specifically concerns physical punishment and that these negative connections do not necessarily hold for other forms of punishment, such as isolation ("on the corridor!") or the withholding of privileges. What's more, she writes that parenting without any punishment probably leads to a strong increase of antisocial behaviour by the children.

\section{Semi-Direct And Free Indirect Writing}

As with speech presentation, reporters may present quotation from written sources as semi-direct writing. In example (16) the reporter semi-directly quotes from a comment in a scientific journal. In this fragment, only at the end of the second sentence does it become clear that the first sentence is a free indirect representation from another written source. 
(16) De makaken hadden de aantallen schijnbaar geabstraheerd, maar hoe? Hier sneuvelt de klassieke theorie, schrijft een commentator bij het bericht in Science. (Trouw, September 6 2002, science)

The macaques had apparently abstracted from the numbers, but how? Here the classical theory fails, writes a commentator as a comment to the article in Science.

Similar to semi-direct speech presentation, semi-direct writing presentation seems to be a mixed type, showing characteristics of both direct and indirect writing presentation.

In short, our newspaper corpus presents cases of direct and indirect writing, as well as semi-direct writing; free direct and embedded writing do not occur, while free indirect writing was rare.

\section{Thought Presentation}

In addition to quoting from other people's speech and writing, in the corpus reporters also quote from thoughts of news sources, or at least, present quotations as such: these quotations are embedded by verbs of thinking, instead of verbs of communication, either with or without the marking of inverted commas (direct and indirect thought presentation).

\section{Direct Thought}

Example (17) shows two cases of direct thought presentation: the first quotation is attributed to newly appointed CEO of Numico for the USA, Peter van Wel, by the verb of thinking "realiseert zich" ("realises"), and the second to an analyst of sNs Securities by the verb "vindt" ("thinks"/"is of the opinion").

(17) "Ik zal voorlopig weinig kunnen genieten van het in Florida volop schijnende zonnetje en van de honderden golfcourses in de omgeving van het nieuwe hoofdkantoor," realiseert hij zich. [...] "Geen sterk verweer," vindt een analist van SNS Securities. "Iedereen denkt nu dat er veel meer aan de hand is." (Telegraaf, March 8 2002, financial news)

"For now I will not be able to enjoy the sun that shines abundantly in Florida, and the hundreds of golf courses in the surroundings of the new head office," he realises. [...] "Not a strong defence," an analyst of sNs Securities thinks. "Now everybody thinks that there is much more going on."

The only formal difference between these examples and the examples of direct speech are the embedding verbs; in speech presentation these verbs are, usually, verbs of communication suggesting speaking, whereas in thought 
presentation the verbs suggest cognitive action on the part of the source of the quotation. This cognitive action is not directly accessible or observable to the reporter, and so the reporter cannot accurately report what is/was thought in any real sense of the term. The question is whether thought presentation, where real persons are involved rather than fictional characters, is the result of reporters inferring thoughts from their utterances or behaviour, or rather of reporter's stylistic variation in representing their speech. In example (17) it seems that the use of thought presentation provides the reporter with a way of varying the embedding of what is actually directly observed speech, and is, hence, merely a stylistic variation by the reporter. This is clearly a difference with fictional narratives, in which narrators frequently represent their characters' imagined thoughts. Reporters can use thought presentation to implicitly represent the deliberations in the consciousness of the original speakers that they observed in their speech and behaviour. They do not reconstruct these thoughts, but use linguistic expressions of perception, cognition, or emotion to represent what they have observed (Sanders, 2010: 229).

\section{Free Direct "Thought"}

Example (18) from an article on various medical treatments for incontinence further illustrates that some cases of thought presentation are actually stylistic variations of speech presentation by the reporter. This example seems to be such a case, as the stretch of free thought does not seem to involve mental deliberations, opinions or thoughts. The verb "vindt" ("thinks") in the first line indicates that this example involves thought presentation, and from that signal, subsequent free direct quote would logically be interpreted as thought presentation as well. From the context it is clear, however, that speech presentation is in order: the source was interviewed by the reporter.

(18) Operaties kunnen bij milde gevallen echter erg ingrijpend zijn, vindt Berghmans. De patiënt moet onder narcose en kan na de operatie nog lang pijnklachten hebben. Daarom doet hij met collega's een onderzoek naar een nieuwe behandelwijze. "Het gaat om een kleine ingreep, waarbij met behulp van een injectienaald siliconen op drie plekken in de wand van de plasbuis worden gespoten." (Algemeen Dagblad, May 10 2002, science)

Operations can, however, be very far-reaching in mild cases, thinks Berghmans. The patient has to be put under an anaesthetic, and might be in pain for a long time after the operation. For that reason he and his colleagues are studying a new treatment method. "It involves a minor opera- 
tion, in which a hypodermic needle injects silicones in three places in the wall of the urethra."

\section{Indirect Thought}

In addition to direct thought presentation, indirect thought presentation occurs in the corpus as well, as in example (19).

(19) Veel mensen menen, dat er aan hart- en vaatziekten weinig of niets te doen valt. (Volkskrant, January 6 2002, science)

Many people think that nothing can be done about cardiovascular diseases.

As is the case in indirect speech, important functions of indirect thought presentation are to summarize and paraphrase (Semino and Short, 2004), particularly when the opinion of a group of people is reported on. This summarizing function is clear in example (19).

\section{Semi-direct Thought}

Similar to semi-direct speech and semi-direct writing, reporters present quotations as well in the form of semi-direct thought. The first sentence of example (18), repeated here as example (20) shows a case of semi-direct thought presentation.

(20) Operaties kunnen bij milde gevallen echter erg ingrijpend zijn, vindt Berghmans. (Algemeen Dagblad, May 10 2002, science)

Operations can, however, be very far-reaching in mild cases, thinks Berghmans.

As was argued for semi-direct speech and semi-direct writing, semi-direct thought presentation is a category that shows characteristics of both direct and indirect thought presentation.

Summarizing, our news corpus presents cases of direct, indirect, and semidirect thought. As opposed to Sanders (2010), no occurrences of free indirect thought presentation were found.

\section{Partial Quotations}

Examples (4) and (8) above have already shown stretches of direct quotation that cannot be straightforwardly categorized as direct speech, because they occur inside other, non-direct quotations. These partial quotations represent less than a complete clause in direct quotation embedded in other types of 
discourse presentation. They occur regularly in our news corpus, which can be explained from the context of news reporting, where using partial quotes enables the reporter to present selected parts of the original utterance, without sacrificing the need for brevity. The words used in partial quotations are generally singled out for the reason that they are particularly apt, shocking, controversial, or revealing; thus they can be used to vividly evoke the original speaker's voice, and/or to convey that the reporter may not want to be associated with these words (Semino and Short, 2004: 154). Thus, the reporter creates liveliness and distance at the same time (Sanders, 2010: 236), as exemplified in (21).

Here, the reporter probably aimed to refuse responsibility for the words of the original speaker - Mrs Rikkers, accused of killing her 4-year-old daughter and of abusing her 3-year-old daughter when she accuses her ex-husband of a range of crimes, including "mogelijk iets met kinderporno" ("possibly something to do with child pornography"). Additionally, by using partial quotations the reporter succeeds in evoking Mrs Rikkers' voice vividly, while still managing to summarize her words.

(21) Rikkers vindt dat "belachelijk." "Ik wil dat Rochelle bij mijn moeder of mijn zus wordt ondergebracht. Anders wil ik dat het kind naar een pleeggezin gaat (...). Iedereen weet wat ik wil." [...] Om haar eisen kracht bij te zetten, beschuldigt zij haar ex-echtgenoot Martin achtereenvolgens van omgang met een jong meisje, xtc- en cocaïnegebruik, overvallen en exhibitionisme in het bijzijn van minderjarigen en "mogelijk iets met kinderporno." Verder beticht zij haar ex-echtgenoot ervan Rochelle "alleen te willen hebben, zodat hij rustig thuis kan zitten met een uitkering." (Telegraaf, March 6 2002, domestic news)

Rikkers thinks that is "ridiculous." "I want Rochelle to be placed with my mother or my sister. If not, I want the child to go to a foster home (...). Everyone knows what I want." [...] To enforce her claims, she accuses her ex-husband Martin successively of contact with a young girl, XTC and cocaine abuse, robberies, and exhibitionism in front of minors, and "possibly something to do with child pornography." Additionally, she accuses her ex-husband of "only wanting to have Rochelle so that he can stay at home on benefits."

Example (21) demonstrates the different forms of partial quotation that occur in the corpus: the partial quotations usually consist of single words ("belachelijk") or phrases ("mogelijk iets met kinderporno") but in some cases even clauses are presented as a partial quotation ("alleen ... uitkering"). The difference with direct speech/writing/thought presentation is that in partial quotations 
the original speaker's words are embedded, both grammatically and semantically, within the reporter's own discourse, whereas direct speech/writing/ thought presentation is typically grammatically independent and semantically separate from the reporter's words (Semino and Short, 2004: 55). The example also shows that partial quotation can be embedded in thought presentation as well as speech presentation, although it is likely that this is a case of thought presentation where the quoted words were originally derived from a spoken interview with the source. As has been argued above, the finite verb "vindt" ("thinks" "is of the opinion") might in this case be actually used as a stylistic alternative to a verb of speaking.

Curiously, in some examples of partial quotation in our corpus, it seems that words are explicitly marked as a verbatim quotation, although it seems unlikely that they have actually been uttered in that way. In example (22), the reporter seems overenthusiastic in marking words as originating from another person, possibly considering it better to avoid possible ambiguity at all cost. The example stems from an article on an alleged fight between a minister and one of his parishioners, and its later court case in which a sergeant who had been called to the scene after the fight gave a testimony of what he had witnessed.

(22) Aan de jas van de dominee, waarvan in het hete van de strijd "alle knopen in het rond zouden zijn gevlogen," had hij niets bijzonders gezien. (Volkskrant, January 11 1950, domestic news)

He had not noticed anything peculiar about the minister's coat, from which in the heat of the fight "all buttons would have come off and flown in the air."

It seems unlikely that the sergeant testifying in court would actually have used the modal verb "zouden," glossed here as "would have," as this modal verb is, typically for journalistic prose, used to introduce the stretch of quotation that it itself is in. ${ }^{7}$ Probably the reporter made a mistake and erroneously included "zouden" in the direct quotation. This fragment raises the question of whether or not there were clear conventions in the 1950's for using inverted commas to mark quotations in news, or whether the conventions for the use of inverted commas were not very strict.

In short, partial quotes are ubiquitous in news narratives, allowing reporters to portray their news sources in a short and vivid manner, while at the same time apportioning responsibility for the wording away from themselves.

7 A case of so-called quotative conditional (see Sanders and Redeker, 1993; Lyons, 1982). 


\section{Conclusion of the Inventory of Quoted Language}

Journalistic narratives seem to put specific demands on the modeling of discourse presentation. Of the pre-described speech/writing/thought presentation modes, direct and indirect speech representation are ubiquitous in news narratives. Direct quotations not only vividly characterize the quoted news sources, they simultaneously function as "grounding" devices: they affirm the presence of the reporter at the news situation and his or her trustworthiness in representing the news source material. Indirect presentation appears to be used for its paraphrasing and summarizing function. In only seven articles free indirect speech presentation was found, restricted to formal news narratives in the 1950's. When comparing older news texts to those more recent, free indirect speech seems to have disappeared, whereas the use of free direct quotations has become common. In addition, the inventory demonstrates that other types of speech presentation are present in our corpus: semi-direct presentation, which allows for rigorous paraphrasing and re-ordering of sentence structure; and partial quotations, which in various forms play an important role in news stories, both in order to enliven in a brief way, and to reject responsibility for the exact wording. Writing presentation is used only in cases where it is to be clarified that the reporter did not actually talk to a source, but read his or her report in written form.

Particularly in thought presentation, the quotations in news narratives differ from quotations in fictional narratives. From the corpus analysis it may be concluded that direct and indirect thought presentation in news is merely used as a stylistic variation on speech presentation, whereas in fiction, the representation of fictional characters' thoughts is an important means to elaborate their inner observations and evaluations, thus sketching their (imaginary) "landscape of consciousness" (Bruner, 1986). In this respect it is important to note that the faithfulness of thought presentation is radically different from speech and writing, because for thought there is no original utterance in news (cf. Semino and Short, 2004: 50); thoughts can be either reconstructed (from utterances and behaviour) or constructed (fictionalized). From the latter option it can be explained that in our news text corpus no cases of free indirect thought were found, while Sanders (2010) found remarkable cases in some longer background articles. Possibly, free indirect thought presentation is used only in extensive news narratives that are meant to elaborate on people in the news by fictionalizing their histories. The function of free indirect thought presentation may thus be to enhance identification with news characters, thus raising understanding for seemingly erratic behaviour (Sanders and Hoeken, this volume; De Graaf et al., 2012). 
The categorization of presentation modes is highly relevant for further investigation of news narratives. It enables researchers to systematically and even automatically analyze corpora of news text, in order to establish the type and proportion of specific categories. By this means, the relative influence of both reporter and news source on the content and wording of quotations can be measured and compared for news narratives stemming from different newspapers, news genres, and periods. This allows for testing hypotheses of "conversationalisation" (Fairclough, 1992) and concomitant increase of subjectivity in news narratives (Vis, 2011). Continuing this line of research, Vis reports that the proportion of direct quotations has vastly increased over the last half century. Thus, systematic corpus analysis can empirically confirm claims of growing liveliness by larger influence of sources in news narratives. In addition, the analyses presented here are relevant to develop further empirical research on narratives, for instance, with respect to the different ways in which readers can learn about the opinions of the main characters in a (news) narrative. It can be hypothesized that readers are more likely to adapt evaluations and attitudes from characters whose speech and thoughts are represented elaborately and in a lively manner in direct or free indirect representation modes than from characters whose utterances are merely paraphrased in indirect representations; also, that these effects are as likely to be found in news narratives as in fictional narratives. Such empirical questions could be put to the test in experimental research of readers' reactions to various representations of source materials.

\section{References}

Bruner, J., Actual minds, possible worlds (Cambridge, 1986).

Clark, H.H. and R.J. Gerrig, "Quotation as demonstration," in Language 66 (1990), pp. 784-805.

De Graaf, A., H. Hoeken, J. Sanders and H. Beentjes, "Identification as a Mechanism of Narrative Persuasion," in Communication Research 39 (2012), pp. 802-23.

Fairclough, N., Discourse and social change (Cambridge, 1992).

Haeseryn, W., K Romijn, G. Geerts, J. de Rooij and M. van den Toorn, ANs. Algemene Nederlandse Spraakkunst Tweede geheel herziene editie (Groningen, 1997).

Leech, G. and M. Short, Style in fiction (London, 1981).

Lok, A., Recht van spreken. Perspectief in veertien journalistieke teksten uit een juridische context uit 1950 en 2002. MA thesis. (vU Amsterdam, 2009). 
Lyons, J., “Deixis and subjectivity: Loquor, ergo sum?" In Speech, place, and action: studies in deixis and other related topics, eds. R. Jarvella and W. Klein (New York, 1982), pp. 101-25.

Rennen, T., Journalistiek als kwestie van bronnen (Delft, 2000).

Sanders, J., "Intertwined voices," in English Text Construction 3(2) (2010), pp. 226-49.

Sanders, J. and H. Hoeken (this volume), Constructing the landscape of consciousness in news stories.

Sanders, J. and G. Redeker, "Linguistic perspective in short news stories," in Poetics 22 (1993), pp. 69-87.

-_- "Perspective and the representation of speech and thought in narrative discourse," in Spaces, worlds and grammar, eds. G. Fauconnier and E. Sweetser (Chicago, 1996), pp. 290-317.

Sanders, J. and W. Spooren, "Subjectivity, perspectivization, and modality from a cognitive linguistic point of view," in Discourse and Perspective in Cognitive Linguistics, eds. W.-A. Liebert, G. Redeker and L. Waugh (Amsterdam, 1997), pp. 85-112.

Semino, E. and M. Short, Corpus stylistics: Speech, thought and writing presentation in a corpus of English writing (London, 2004).

Vis, K., Subjectivity in news discourse. A corpus linguistic analysis of informalization. $\mathrm{PhD}$ Dissertation. (vu Amsterdam, 2011).

Vis, K., W. Spooren and J. Sanders, "Using Rst to analyze subjectivity in text and talk," in Cognitive Linguistics in Action, eds. E. Tabakowska, M. Choiński and Ł. Wiraszka (Berlin, 2010), pp. 293-316.

Waugh, L., "Reported speech in journalistic discourse: the relation of function and text," in Text, 15(1) (1995), pp. 129-73.

Weizman, E., "Some register characteristics of journalistic language: are they universals?" In Applied Linguistics 5 (1984), pp. 39-50. 
PART 3

Image and Text

$\because$ 